\title{
Temporal and Spatial Variations in Total Suspended and Dis- solved Solids in the Upper Part of Manoa Stream, Hawaii
}

\author{
Denie Augustijn ${ }^{*}$, Ali Fares², and Dai Nghia Tran ${ }^{3}$
}

1 Water Engineering and Management, University of Twente, P.O. Box 217, 7500 AE Enschede, The Netherlands. ${ }^{2}$ Watershed Hydrology Laboratory, Department of Natural Resources and Environmental Management, College of Tropical Agriculture and Human Resources, University of Hawai'i at Manoa, 1910 East-West Road, Honolulu, HI 96822. ${ }^{3}$ The College of Economics and Business Administration, Thai Nguyen University, Vietnam.

Received: April 30, 2010 / Accepted: December 16, 2010

\begin{abstract}
$\mathrm{H}$ awaiian watersheds are small, steep, and receive high intensity rainfall events of non-uniform distribution. These geographic and weather patterns result in flashy streams of strongly variable water quality even within various stream segments. Total suspended solids (TSS) and total dissolved solids (TDS) were used to investigate the variability in water quality in the upper part of Manoa Stream in Honolulu, Hawaii. With a few interruptions, water samples were taken on a daily basis between September 2005 and June 2006. The samples were analyzed for TSS and TDS, and varied from almost 0 to 724 and to $302 \mathrm{mg} \mathrm{L}^{-1}$, respectively. During the raining season (October through March) TSS and TDS were more variable, and TSS was higher than in the dry season (April through June). No relation was observed between TSS and TDS and discharge. This may be explained by the heterogeneous rainfall distribution which causes varying contributions from different sources. During one rainfall event TSS and TDS also varied considerably in time. Both TSS and TDS showed increasing trends going downstream suggesting that the urbanized area generates more suspended and dissolved matter than the forested conservation area upstream. However, given the large variability in TSS and TDS, the increasing trend downstream is associated with high uncertainty. The results of this study stress the necessity of recognizing the variability in water quality of small streams for setting up a monitoring strategy, adopting a modeling approach to predict water quality or extrapolating data from limited samples to annual loads in coastal regions.
\end{abstract}

* Corresponding author: d.c.m.augustijn@utwente.nl
Keywords: total suspended solids (TSS), total dissolved solids (TDS), Manoa Stream, Hawaii, temporal and spatial variations.

\section{Introduction}

Hawaiian streams have very unique characteristics as these flashy water bodies flow through small and steep watersheds and cut through highly weathered volcanic soils (Oki and Brasher, 2003; Polyakov et al., 2007). Many streams are highly influent, losing water by seepage through the permeable basalts that can emerge again as springs below sea level. Runoff and stream flow are generated when the infiltration capacity is exceeded and are strongly influenced by the steep slopes and storm patterns that are often very intense but short, causing streams with a flashy nature. For the assessment of ecological sustainability, the water quality of Hawaiian streams is of major concern because streams form a short and direct route of land-based pollutants to the ocean where they cause a primary threat for coral reef ecosystems. The pollutants reach the streams by soil erosion and urban runoff. Soil erosion is enhanced by poor land-use practices, human activities, invasive alien plant species, and feral ungulates (wild boars and goats) and increases suspended solids, nutrients and pathogens in surface water. Storm-water runoff from urbanized areas carries particulate and dissolved matter to the streams that contain pollutants like metals and pesticides. This emphasizes a critical need to evaluate erosion, sedimentation, and water quality dynamics on watershed scale in Hawaii (Calhoun and Fletcher, 1999). Determining stream water fluxes 
and sediment loads into coastal areas is essential to determine the stress on coral reef ecosystems in the coastal zone, which are very sensitive to contamination. Moreover, contamination of coastal zones may have negative effects on the tourism industry, which is vital for Hawaii's economy.

Precipitation in Hawaii is characterized by large spatial and temporal variations of rainfall (Giambelluca et al., 1986). The variability is caused by the rain formed within the moist air as it ascends steep terrain, resulting in rainfall distribution resembling topographic contours on windward slopes (Polyakov et al., 2007). The highly spatio-temporal variability of rainfall, stream flow characteristics, and hydrological response in these flashy streams make stream water quality assessment unique and challenging.

Literature reveals many water-quality studies in Hawaii (Oki and Brasher, 2003). In these studies Manoa Stream appears regularly as an example of a contaminated stream. Manoa Stream, one of 366 perennial streams on the five major Hawaiian Islands (Stone, 1989), is a prominent urban stream that drains a broad valley in the Honolulu area and has been part of the National Contaminant Biomonitoring Program (NCBP) (Schmitt et al., 1999) and the National Water-Quality Assessment (NAWQA) program (Anthony et al., 2004) as a waterquality limited segment. Many water-quality studies in Hawaii show high variability in measured water-quality parameters. General trends in these variations, especially differences in concentrations between base flow and storm flow, have been used to elucidate sources and transport mechanisms of contaminants in Manoa watershed (De Carlo et al., 2004; Anthony et al., 2004). For reliable water-quality assessment, prediction or extrapolation of water-quality data to annual loads, additional information is needed on the spatial and temporal variability of runoff and sediment loading across the watershed.

In this study total suspended solids (TSS) and total dissolved solids (TDS) will be used to characterize the variability in water quality in the upper part of Manoa Stream. TSS and TDS are good indicators of physical, chemical, and aesthetic degradation and often explain most of the variability in multivariate statistical analysis of water quality parameters (e.g., Miserendino et al., 2008; Najafpour et al., 2008). Suspended-sediment load or water-column indicators are one of the five broad categories that are applicable to sediment total maximum daily loads (TMDLs) indicators (U.S. Environmental Protection Agency, 1999). TSS represents the organic and inorganic particulate material in the water column larger than $0.45 \mu \mathrm{m}$. Often a large portion of the reactive contaminants is associated with the suspended solids fraction. TDS is a measure of the amount of material dissolved in a water sample. This material includes dissolved minerals and organic matter, but can also include contaminants.

In a stream, both TSS and TDS vary spatially and temporally due to natural and anthropogenic factors such as climate, soil type, relief and land use (Walling and Webb, 1992; Webb and Walling, 1992). Evaluating the relation of TSS and TDS with rainfall and stream discharge for a better understanding of the runoff mechanisms can help developing a watershed management plan for protection of water resources and the environment. We are specifically interested in the impact of the urbanized part of the watershed on water quality. The objectives of this study were to: 1) examine the temporal and spatial variations of TSS and TDS in Manoa Stream; and 2) understand the relation of TSS and TDS with rainfall and stream discharge

\section{Materials and Methods}

\subsection{Study Area and Sampling Locations}

Manoa watershed is located between the Koolau Range and Mamala Bay on the island of Oahu, Hawaii (Figure 1). Manoa Stream starts in the forested area along the Koolau Range, with the highest elevation at $960 \mathrm{~m}$. The upper portion of the stream, upstream of the US Geological Survey (USGS) stream gauge at Kanewai Field (site 4 in Figure 1), has a catchment area of 15.5 $\mathrm{km}^{2}$. Before the stream enters the urbanized area at an elevation of approximately $89 \mathrm{~m}$ above mean sea level, several tributaries flow together draining a steep mountainous and deep fluvial valley of $2.7 \mathrm{~km}^{2}$ conservation area. The urban area is mainly residential. In the urban area, the stream is channelized with concrete over certain reaches. At several locations storm water drains into the stream. Eventually, Manoa Stream combines with the Palolo Stream to the Manoa-Palolo Canal that drains in the Ala Wai Canal bordering the tourist enclave of Waikiki. The Ala Wai Canal drains into the Pacific Ocean at Mamala Bay. Year round orographic rainfall is the primary source of stream water. The stream with steep headwater sections and rather gentle low reaches, has a flashy nature, i.e., storm flows peak and recede within hours (Anthony et al., 2004). Tidal effects and salt-water intrusion can propagate up to the Manoa-Palolo Canal especially at high water during spring tide (Tomlinson and De Carlo, 2003).

Five sampling locations were selected along Manoa Stream across the watershed (Figure 1, Table 1). To investigate the temporal variability of TSS and TDS in Manoa Stream water samples were taken daily with a few interruptions during the period of September 2005 to June 2006 at the Japanese Garden of the University of Hawaii at Manoa (UHM) (site 3). For variations during a rainfall event, multiple samples were taken during several rainy days also at site 3 . Water samples at all five locations were collected simultaneously on three different days to quantify the spatial variability. Site 1 is at Lyon Arboretum in the forested part of the watershed, the other sites are in urbanized area. In addition to water-quality sampling, daily rainfall data were obtained from the National Weather Service (NWS) station at Lyon Arboretum (site 1) and discharge data were obtained from the USGS gauge at Kanewai Field (USGS 16242500; site 4). Results from this study are compared with the TSS and TDS data acquired from Department of Environmental Services (DES) collected monthly in the period July 2005 through June 2006 at Kanewai Field (site 4) and sampling locations in two different tributaries just upstream of the urban area (DES, 2006).

\subsection{Sample Collection and Analysis}

Stream water samples were collected by a grab sampling 
Table 1. Sampling sites, their geographic locations, elevation, distances and the measured parameters.

\begin{tabular}{|c|c|c|c|c|c|c|}
\hline Site & Location & $\begin{array}{l}\text { Latitude } \\
\text { (Deg.) }\end{array}$ & $\begin{array}{l}\text { Longitude } \\
\text { (Deg.) }\end{array}$ & $\begin{array}{l}\text { Elevation } \\
\text { (m) }\end{array}$ & $\begin{array}{l}\text { Distance from } \\
\text { site } 1^{b}(\mathrm{~km})\end{array}$ & $\begin{array}{l}\text { Measured } \\
\text { Parameter }\end{array}$ \\
\hline 1 & Lyon Arboretum & 21.334 & -157.803 & 143 & 0 & TSS, TDS Rainfall \\
\hline 2 & Manoa Shopping Center & 21.308 & -157.809 & 62 & 3.8 & TSS and TDS \\
\hline 3 & Japanese Garden at UHM Campus ${ }^{a}$ & 21.299 & -157.813 & 31 & 5.0 & TSS and TDS \\
\hline 4 & Kanewai Field & 21.292 & -157.814 & 12 & 5.9 & TSS, TDS Discharge \\
\hline 5 & Confluence of Manoa and Palolo Streams & 21.291 & -157.815 & 2 & 6.2 & TSS and TDS \\
\hline
\end{tabular}

${ }^{a}$ UHM is University of Hawaii at Manoa. ${ }^{b}$ Approximate distance along the stream from site 1 at Lyon Arboretum.
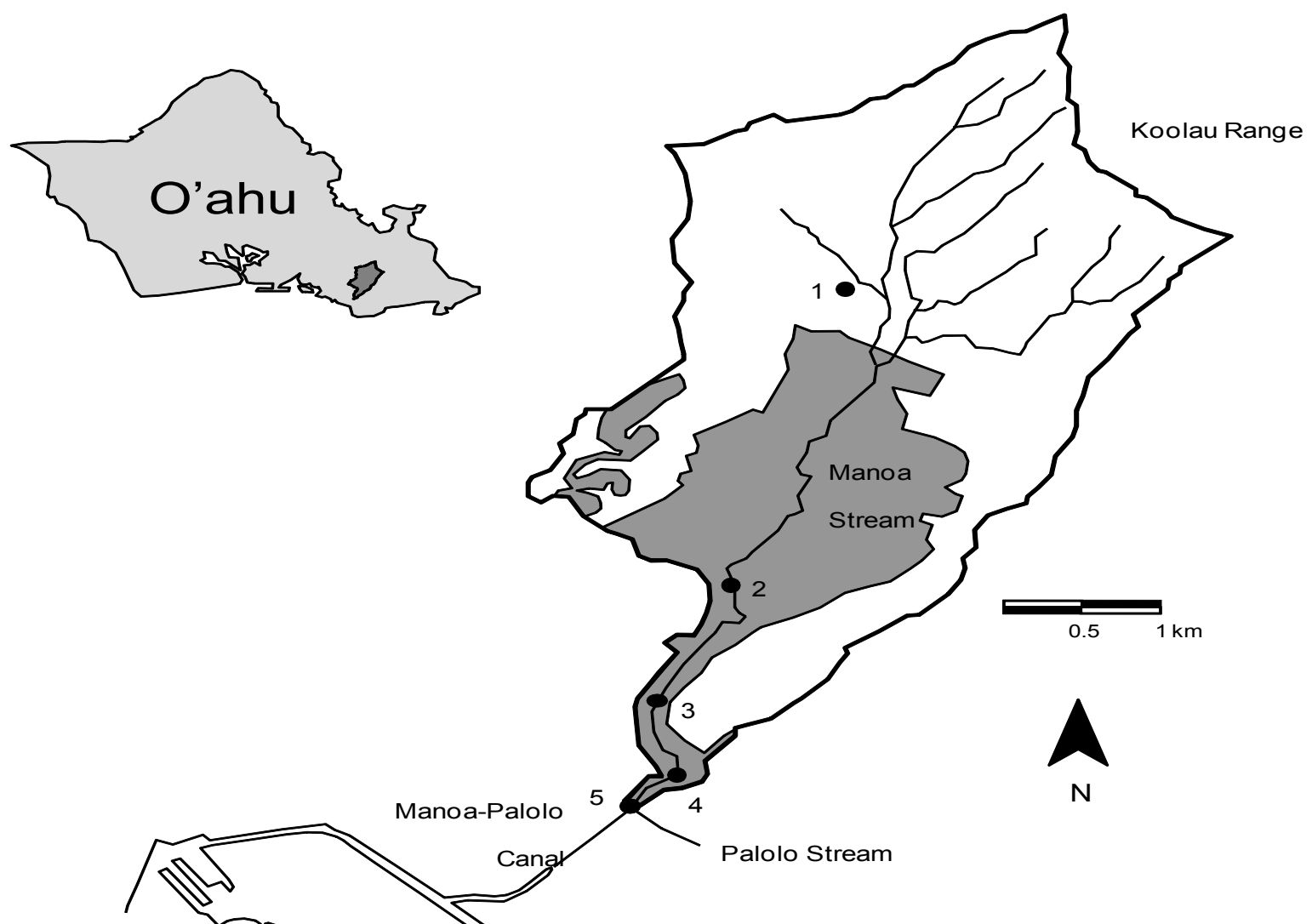

$\mathrm{N}$

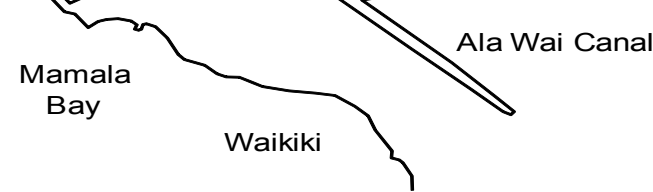

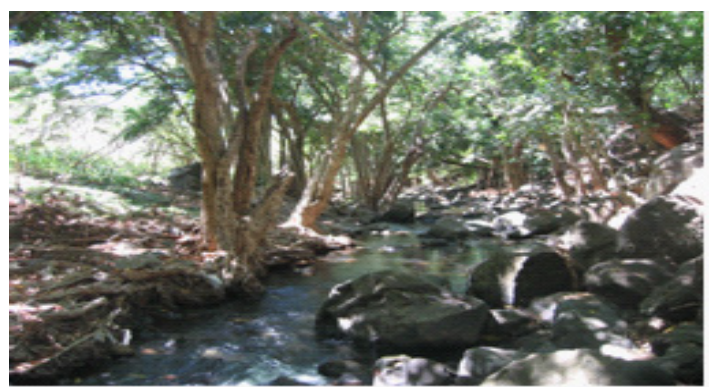

Site 3 Japanese garden at UHM

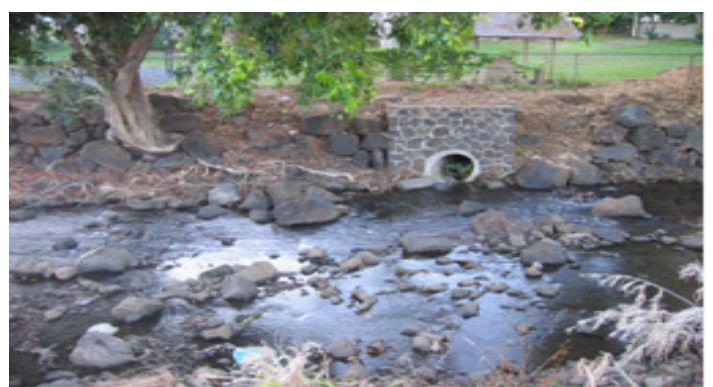

Site 4 Kanewai Field

Figure 1. Study location and sampling sites across Manoa Stream in Manoa Watershed, Oahu, Hawaii. The grey area is built-up area. 
method and were analyzed for TSS and TDS following the EPA 160.1 and 160.2 methods (US Environmental Protection Agency, 1983). Water samples were collected in a $1 \mathrm{~L}$ glass bottle from approximately mid-depth of the stream flow. Bottles were rinsed with stream water and emptied before refilling for analysis. Samples were stored at $4^{\circ} \mathrm{C}$. Before analysis the bottles were shaken again to ensure sample homogeneity. A $100 \mathrm{~mL}$ sub-sample was taken and passed through a pre-weighed 0.45 $\mu \mathrm{m}$ filter using a filter funnel and vacuum suction. The residue retained on the filter was oven dried at $105^{\circ} \mathrm{C}$ for 24 hours to obtain TSS. The filtrate was collected in a $150 \mathrm{~mL}$ glass container and dried in a furnace at $158^{\circ} \mathrm{C}$ for $24-48$ hours and weighed to obtain TDS. The data acquired from Department of Environmental Services (DES, 2006) were analyzed according to the same EPA methods.

\section{Results and Discussion}

\subsection{Rainfall Versus Discharge}

Assuming that discharge would increase with rainfall intensities, the relation between daily rainfall and discharge was evaluated. The daily rainfall at Lyon Arboretum (site 1; Figure 1), the daily discharge measured at Kanewai Field (site 4; Figure 1 ), and their correlation are shown in Figure 2 and 3. Discharge data from Kanewai Field were only available until the end of February 2006. Figure 2 depicts that discharge peaks downstream often correspond with a rainfall event up in the mountains on the same day or a day earlier, but that not all high rainfall events lead to a distinct discharge peak. The daily discharge at Kanewai Field has weak correlation $\left(R^{2}=0.42\right)$ with the rainfall in the upper part of the valley (Figure 3), most likely due to the heterogeneous distribution of rainfall over the watershed and variable losses of water by seepage and evaporation.

\subsection{Variations in TSS and TDS Over Sampling Period}

Results of temporal variation in TSS and TDS concentrations measured at UHM (site 3) have three distinct seasonal patterns (Figure 4 and Table 2): 1) in September-October (2005) TSS concentrations were quite variable and relatively high (TDS data from this period are suspected to be incorrect and are not presented here); 2) between December (2005) and March (2006), both TSS and TDS concentrations showed significant variability and TSS concentrations were generally lower than in September-October; and 3) between April (2006) and July (2006), which is in the dry season, TSS and TDS concentrations were more constant with TSS having values near zero and TDS concentrations in the same range as previous period. In the period April 2006 to July 2006, only rainfall events with relatively low intensities occurred which likely have generated minimal runoff and thus low TSS concentrations. From September to April, more rainfall events occurred, often with high intensities, that produced excess runoff resulting in high TSS concentrations. The variability in TSS and TDS in this period can be related to the irregularity in rainfall, where TSS is likely to increase with rainfall intensity while TDS is likely to decrease during and follow-
Table 2. Comparison of statistical indices of daily TSS and TDS data between this study and measurements reported by Department of Environmental Services for Manoa Stream (DES, 2006).

\begin{tabular}{|c|c|c|c|c|c|c|c|}
\hline \multirow{2}{*}{ Period } & \multirow{2}{*}{$n^{a}$} & \multicolumn{3}{|c|}{$\operatorname{TSS}\left(\mathrm{mg} \mathrm{L}^{-1}\right)$} & \multicolumn{3}{|c|}{$\operatorname{TDS}\left(\mathrm{mg} \mathrm{L}^{-\cdot}\right)^{c}$} \\
\hline & & range & average & St. dev. ${ }^{b}$ & range & average & St. dev. \\
\hline \multicolumn{8}{|l|}{ This study: } \\
\hline Sep-Oct 2005 & 23 & $18-742$ & 483 & $168(35 \%)$ & & & \\
\hline $\begin{array}{l}\text { Dec } 2005- \\
\text { Mar } 2006\end{array}$ & 68 & 1.330 & 85 & $65(76 \%)$ & 3.254 & 107 & $53(50 \%)$ \\
\hline $\begin{array}{l}\text { Apr-Jun } 2006 \\
\text { DES: }\end{array}$ & 38 & 0.28 & 6.5 & $4.9(76 \%)$ & $17-302$ & 131 & $42(32 \%)$ \\
\hline $\begin{array}{l}\text { Jul } 2005- \\
\text { Jun } 2006\end{array}$ & 12 & $4-228$ & 27.2 & $63.4(233 \%)$ & 76.196 & 129 & $34(26 \%)$ \\
\hline
\end{tabular}

${ }^{a} \mathrm{n}$ is number of samples during given period. ${ }^{b}$ Standard deviations are also given as percentages of the average in parentheses. ${ }^{~}$ Values for TDS in September-October 2005 are suspected incorrect and therefore omitted. ${ }^{d}$ Department of Environmental Services.

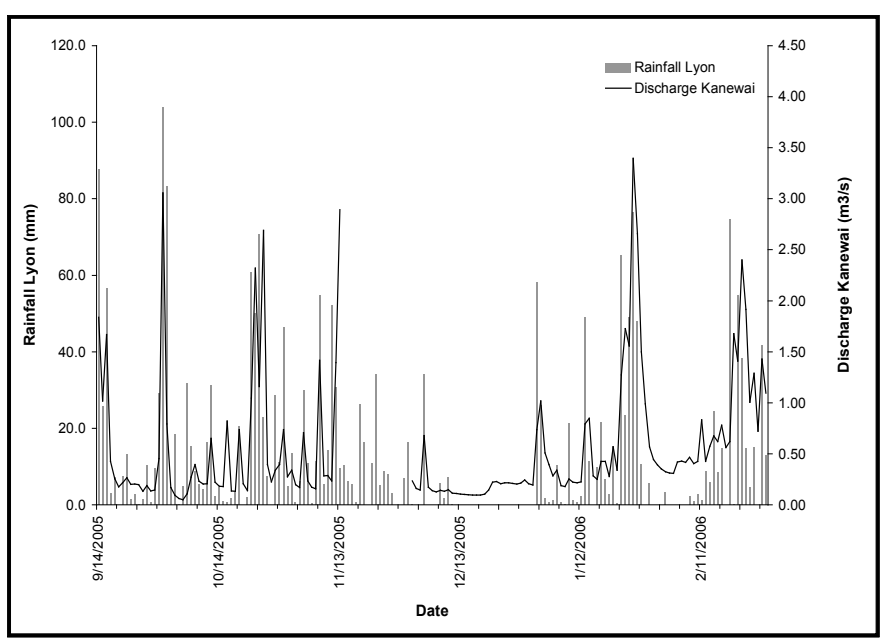

Figure 2. Daily rainfall at Lyon Arboretum (site 1) and daily discharge at Kanewai Field (site 4) available for the sampling period from September 14, 2005 through February 27, 2006. Rainfall data is complete, discharge data is missing for 17 days in November.

ing storm events due to dilution. The monthly TSS and TDS data reported by Department of Environmental Services (DES, 2006), measured at Kanewai Field over about the same period, are in the same range as the values obtained in this study (Table 2), however, no distinct seasonal differences can be distinguished. Values for TSS are generally low, between 4 and $19 \mathrm{mg} \mathrm{L}^{-1}$, with one outlier of $228 \mathrm{mg} \mathrm{L}^{-1}$ in November 2005.

Changes in TSS and TDS with discharge depend on the distribution of sources (e.g., land use and anthropogenic activities, soils and underlying rock mineralogy) and the interaction of water with these sources. The interaction of water with sources is controlled by factors that include rainfall intensity, duration, and distribution, soil and streambed permeability, topography, geology, and the presence of man-made drainage ways. Figure 5 shows TSS and TDS data at UHM (site 3) as a function of the average daily discharge at Kanewai Field (site 4). There appears to be no correlation of neither TSS nor TDS with discharge. This is also the case for the data acquired from Depart- 


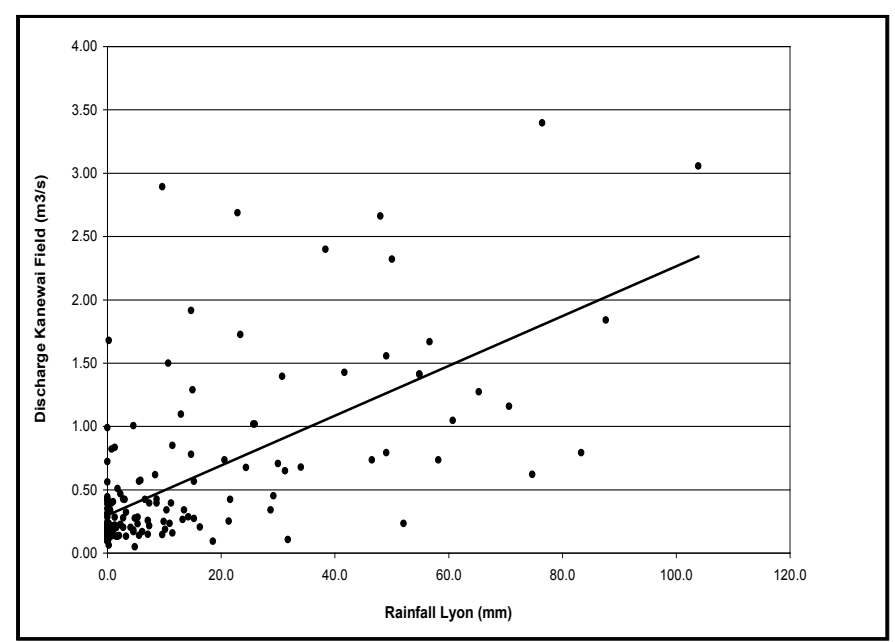

Figure 3. Correlation between daily rainfall at Lyon Arboretum and daily discharge at Kanewai Field (September 14, 2005 - February $27,2006)$. Trend line gives best linear fit: $y=0.02 x+0.3\left(R^{2}=0.42\right)$.
Table 3. Statistical summary of variability in TSS and TDS within one day.

\begin{tabular}{ccccccc}
\hline \multirow{2}{*}{ Date } & Rainfall $^{a}$ & \multirow{2}{*}{$n^{b}$} & \multicolumn{2}{c}{ TSS (mg L $\left.L^{-1}\right)$} & \multicolumn{2}{c}{ TDS (mg L $\left.L^{-1}\right)$} \\
\cline { 4 - 7 } & $(m m)$ & & average & St. dev $^{c}$ & average & St.dev \\
\hline $1 / 23 / 2006$ & 23.4 & 4 & 29.3 & $10.3(35 \%)$ & 80.6 & $52.3(65 \%)$ \\
$2 / 20 / 2006$ & 54.9 & 2 & 96.5 & $29.0(30 \%)$ & 80.5 & $38.9(48 \%)$ \\
$2 / 24 / 2006$ & 15.0 & 2 & 155.0 & $89.1(57 \%)$ & 74.0 & $21.2(29 \%)$ \\
$2 / 27 / 2006$ & 13.0 & 5 & 804.0 & $17.7(22 \%)$ & 163.6 & $11.8(7 \%)$ \\
$2 / 28 / 2006$ & 13.2 & 2 & 67.0 & $11.3(17 \%)$ & 164.5 & $23.3(14 \%)$ \\
$3 / 1 / 2006$ & 68.1 & 2 & 81.5 & $54.4(66 \%)$ & 108.5 & $30.4(10 \%)$ \\
$3 / 2 / 2006$ & 29.7 & 8 & 114.8 & $28.8(25 \%)$ & 156.0 & $16.3(57 \%)$ \\
$3 / 3 / 2006$ & 54.6 & 3 & 97.0 & $20.7(21 \%)$ & 153.7 & $87.9(57 \%)$ \\
$4 / 2 / 2006$ & 25.7 & 4 & 654.5 & $343.8(52 \%)$ & 31.8 & $24.5(77 \%)$ \\
$5 / 15 / 2006$ & 8.9 & 2 & 92.5 & $6.4(7 \%)$ & 193.5 & $33.2(17 \%)$ \\
\hline
\end{tabular}

a Rainfall measured at Lyon Arboretum (site 1, Figure 1). ${ }^{b} \mathrm{n}$ is number of samples analyzed for given days. ${ }^{c}$ Standard deviations are also given as percentages of the average in parentheses.

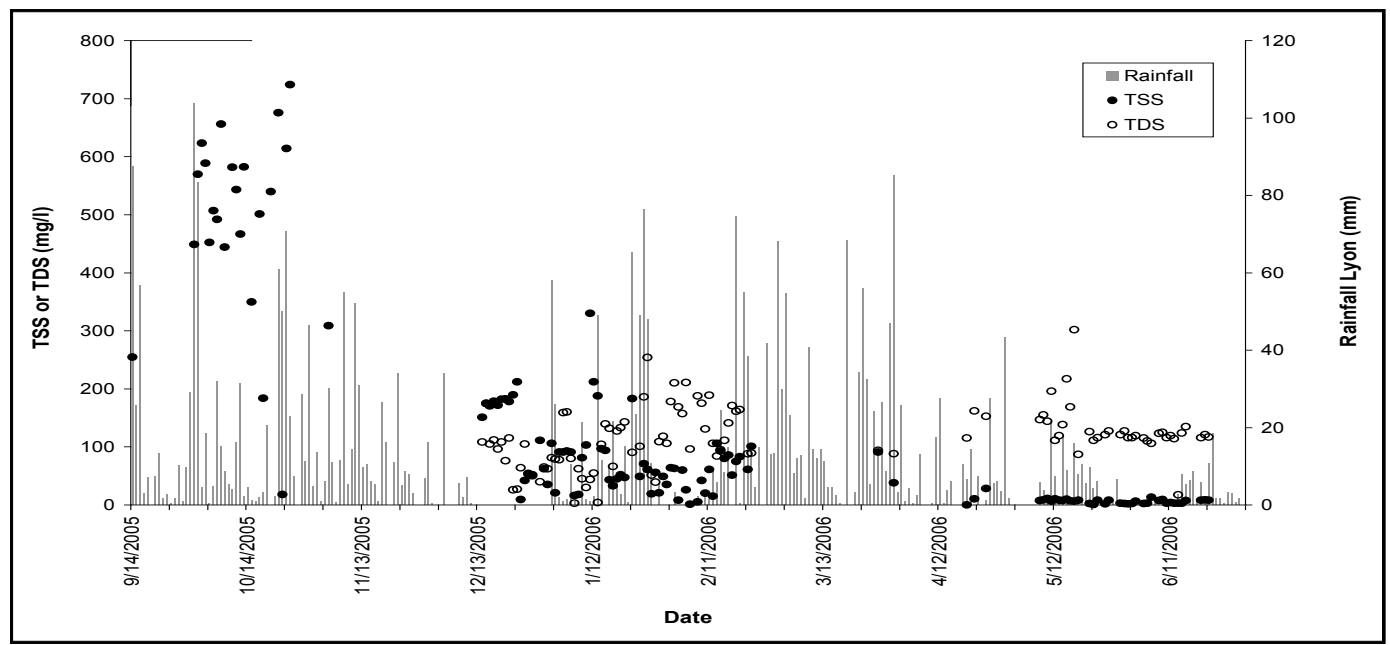

Figure 4. Concentrations of TSS and TDS measured at Japanese Garden of the University of Hawaii at Manoa (UHM) (sampling site 3) and daily rainfall measured at Lyon Arboretum (site 1) during the study period September 2005 through June 2006.

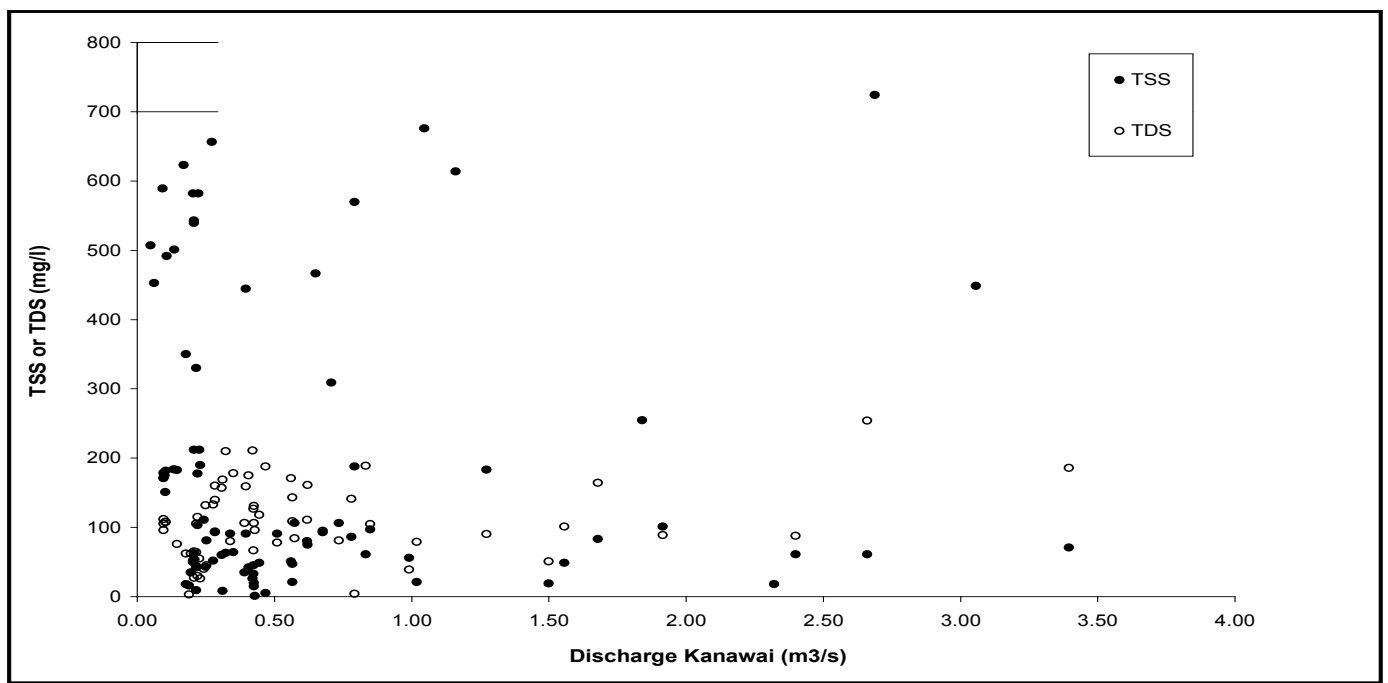

Figure 5. Correlation between TSS and TDS concentrations and daily average discharge at Kanewai Field (site 4) during the study period September 2005 through June 2006. 
ment of Environmental Services (DES, 2006). The weak correlation between rainfall and discharge (Figure 3) may explain the lack of correlation between discharge, and TSS and TDS. Notably, a weak correlation between TSS and discharge is typical of supply-limited sediment transport systems, which have been related to seasonal effects, hysteresis effects during individual runoff events, and progressive sediment depletion during successive runoff events (Moliere et al., 2004). Non-uniform stream cross-sections may also contribute to irregular sediment supply and entrapment with changing discharge (Osterkamp, 2002). Lim (2003) attributed scatter in the sediment-rating curve to first-flush effects and incidental point sources. Examples of the latter are bank collapse and washout of material or construction activities, which can have significant impacts on stream water quality in small watersheds. These results coincide with the conclusions of McMurtry et al. (1995) who, based on the analysis of radionuclides, found that sediment accumulation in Ala Wai Canal is not always correlated to high rainfall and explained observed variability by complex mechanisms of soil erosion. TDS is generated from the contribution of different components to the stream flow such as groundwater, subsurface flow, and surface runoff (Evans and Davies, 1998). Temporal and spatial differences in these contributions cause scatter in the relation between TDS and discharge.

Meybeck et al. (2003) classified different rivers around the world based on TSS concentrations. They stated that natural steep volcanic watersheds usually have very high dischargeweighted TSS of 2000-10,000 $\mathrm{mg} \mathrm{L}^{-1}$. The discharge-weighted TSS in our study is only $187 \mathrm{mg} \mathrm{L}^{-1}$, which is in the medium range as classified by Meybeck et al. (2003). Reduction in TSS, compared to what is considered natural, might be due to urbanization of a large part of the studied watershed, with its paved surfaces that reduce erosion and increase sediment entrapment. On the other hand, sediment loads of highly-urbanized areas can be significant due to road runoff, construction sites, industrial point sources, channel erosion, and waste water (Owens et al., 2005; Chin, 2006; Taylor and Owens, 2009). In Manoa valley houses are mainly residential, waste water is collected via a separate sewage system and treated elsewhere, and parts of the stream have been stabilized by concrete limiting channel erosion. Hence, suspended sediments originate most likely from erosion upstream of the urban area, urban runoff, and to some extend channel erosion. Urban runoff from paved and unpaved surfaces is likely the main source of contaminants originating from traffic, pest control, material leaching, and construction activities. De Carlo and Anthony (2002) found that $\mathrm{Cu}, \mathrm{Pb}$, and $\mathrm{Zn}$ in stream-bed sediments of Ala Wai Canal watershed generally increase downstream owing to increased contributions from urban areas, especially road runoff. Sutherland (2000) concluded that traffic is the major anthropogenic source for heavy metals associated with sediment particles in Manoa Stream. The impact of the urbanized part of the watershed on TSS and TDS concentrations in Manoa Stream will be evaluated in section 3.4.

\subsection{Variations in TSS and TDS During a Rainfall Event}

At site 3 (UHM Japanese Garden), TSS and TDS concentra-
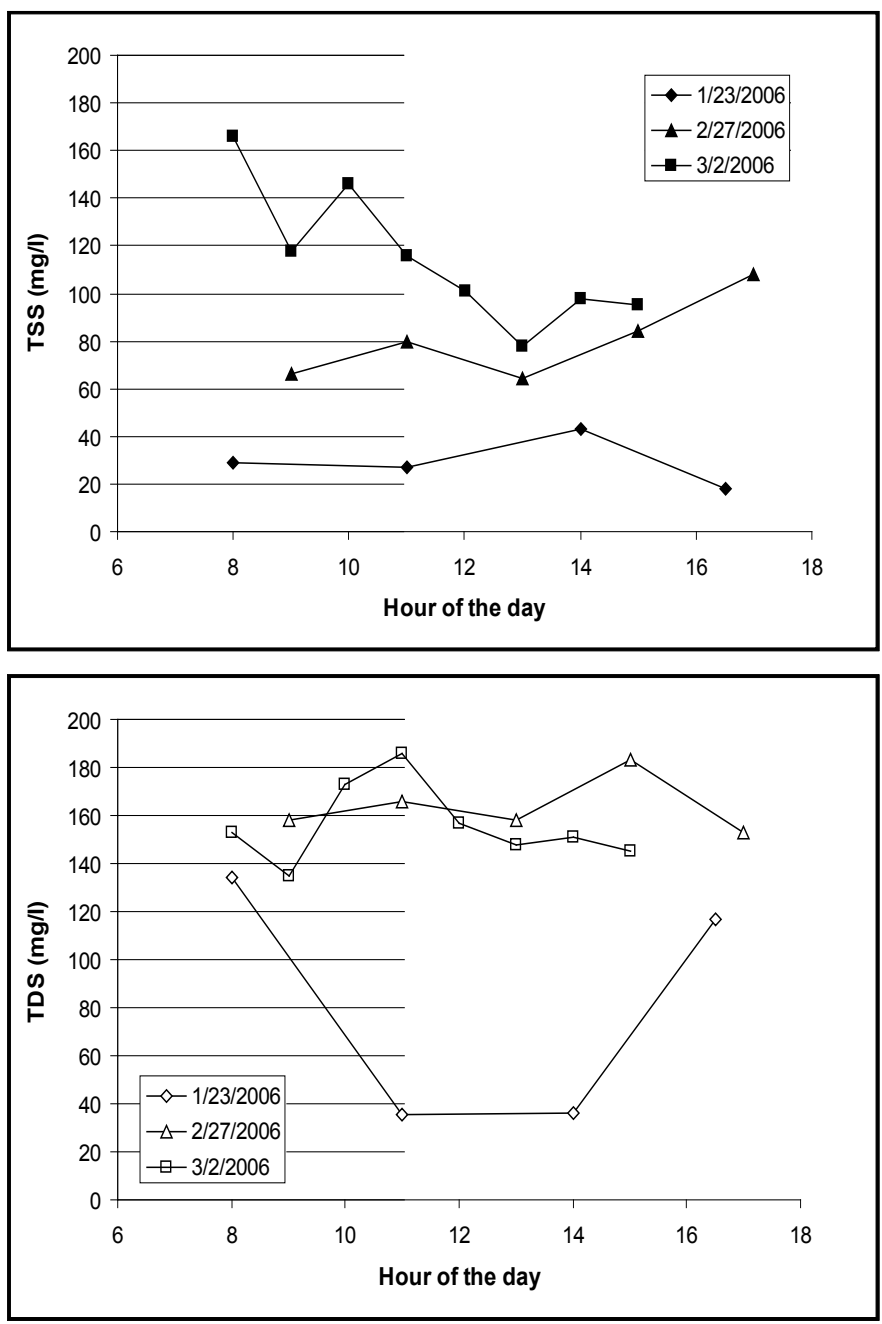

Figure 6. Concentrations of (a) TSS and (b) TDS measured at different times during one day for three different dates of the study period.

tions were measured during different rainy days. The results are presented in Table 3 and some of them are graphically visualized in Figure 6. These results show that during a given rainy day there can be a large variability in TSS and TDS concentrations, and that one grab sample may not represent the sediment concentration during the entire day or storm event. The overall variability for TSS and TDS is found to be in the same range $(7-77 \%$ ) (Table 3 ); however, the variability in each of the parameters can be quite different for a given day.

\subsection{Spatial variations in TSS and TDS}

To investigate the spatial variability of TSS and TDS in Manoa Stream, samples were taken simultaneously at five different locations along the stream (for locations see Figure 1) on three different days. On January 24 and February 22 the discharge was relatively high $\left(1.56 \mathrm{~m}^{3} \mathrm{~s}^{-1}\right.$ and $1.91 \mathrm{~m}^{3} \mathrm{~s}^{-1}$, respectively), on February 7 the discharge was about average $\left(0.42 \mathrm{~m}^{3} \mathrm{~s}^{-1}\right)$. The results show that TSS and TDS concentrations tend to increase from the upstream to the downstream region (Figure 7). Site 1 is upstream from Lyon Arboretum and represents the upstream forested area. In general, 

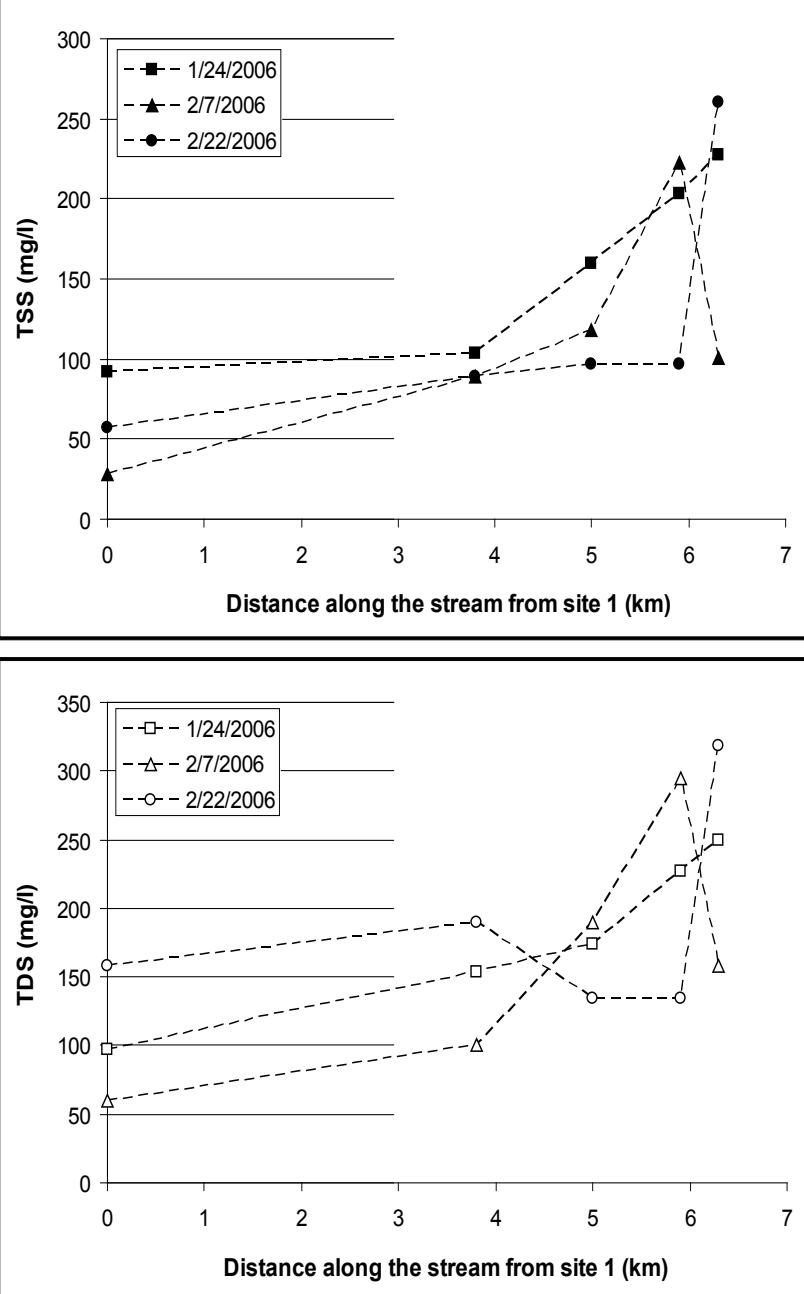

Figure 7. Concentrations of (a) TSS and (b) TDS at five different locations along Manoa Stream sampled at the same time during the study period.

this site has the lowest concentrations meaning that more suspended and dissolved solids enter the stream downstream from this site. Between site 1 and 2 some tributaries and several storm water drains enter Manoa Stream, but at site 2, which borders the parking lot of a shopping center, the concentrations of TSS and TDS are only slightly higher than at site 1. This either means that the supply of suspended and dissolved solids by the stream and the lateral inflows is limited or that the solids are trapped before the sampling point. TSS and TDS concentrations show a notable increase at the three most downstream sites. Between site 2 and 3 the stream runs along the slope of Waahila Ridge and continuous through urbanized area with storm drains entering the stream at various places. Apparently, water entering the stream in these reaches has higher concentrations in TSS and TDS than the water entering more upstream. A similar trend can be observed in the data reported by Department of Environmental Services in which the TSS and TDS values measured at Kanewai Field were in almost all cases consistently higher than the values measured in two tributaries just upstream of the urban area (DES, 2006). This suggests that the forested lands protect their soils better than the downstream urban land uses and are less likely to generate excessive sediments. TSS concentration is also determined by resuspension and settling velocities. These depend on stream flow velocity which in its turn depends on discharge, slope, cross section, and flow resistance due to bottom roughness, vegetation or obstacles like boulders or debris, which can all vary locally. In addition, spatial variations in TSS and TDS can also be affected by the proximity of sources. Moreover, given the temporal variations discussed above the observation of an increasing trend of TSS and TDS in downstream direction is associated with high uncertainty.

Knowledge of spatial variability of water quality is important when annual loads of sediment are calculated. Fluxes of contaminants through the water column of a stream vary throughout a watershed. In general, streambed slopes decline toward the coast reducing flow velocities and facilitating settlement of suspended sediment. Changes in salinity and $\mathrm{pH}$ will also affect the flocculation and sedimentation of suspended and dissolved solids. Hence going downstream bed load may gain importance in the total transport of contaminants. For Manoa Stream, as the Ala Wai Canal acts as a sediment trap, the retention of contaminants not only impairs the chemical and ecological quality of the Ala Wai Canal, but also reduces the outflow to the ocean. For other streams in Hawaii a similar mechanism of retention occurs. Most Hawaiian streams are not permanently connected to the ocean but separated by a sand dune behind which settlement of sediments can take place. Only during high stream discharges or high tides ocean and streams are interconnected and sediments can be exchanged.

\section{Conclusions}

Hawaiian streams are characterized by quick and large changes in discharge which has its impact on water quality parameters. Total suspended and total dissolved solids measured, with some interruptions, on a daily basis between September 2005 and June 2006, were used to investigate water quality variations in the upper part of Manoa Stream, on the island of Oahu. Both TSS and TDS show irregular temporal and spatial variations; TSS varied between 0 and $724 \mathrm{mg} \mathrm{L}^{-1}$ and TDS varied over a narrower range of $3-302 \mathrm{mg} \mathrm{L}^{-1}$. Seasonal patterns of TSS and TDS were attributed to rainfall events with high or low intensities and associated runoff. Higher and more variable TSS and TDS values were observed during the rainy seasons (September-October 2005 and December 2005 through March 2006) than in the dry season (April 2006 through June 2006) when relatively lower and constant values of TSS and TDS were observed.

There was only a weak correlation between upstream rainfall and downstream discharge, probably due to a heterogeneous distribution of rainfall over the watershed and loss of water due to seepage and evaporation. This may also explain the lack of correlation between TSS and TDS and stream discharge. The scatter in the sediment-rating curve for TSS and TDS may also be explained by supply-limited conditions for sediment and varying local conditions. Concentrations of TSS and TDS tended to increase from upstream to downstream, suggesting that the forested soils in the upper watershed of the Manoa Stream gen- 
erate less suspended and dissolved solids than the urbanized area downstream. However, given the diurnal variations at these locations, the increasing spatial trend in TSS and TDS towards the ocean is associated with high uncertainty.

This study reveals short-term variations in TSS and TDS of Manoa Stream. These variations are mostly irregular and only follow weak patterns. The results provide a general idea about the spatial and temporal water quality variations but also indicate that precise prediction of water quality based on physical models will be very difficult. High-resolution sampling for an extended period will help in assessing the water quality of strongly variable urbanized streams like Manoa Stream; however, this can be very expensive and the true variations may never be captured. This study points out that when setting up a monitoring strategy or model the objective should be clear and the spatial and temporal variability in water quality parameters should be recognized.

\section{Acknowledgements}

The project was partially supported by a grant from the U.S. Department of Agriculture Mclntire-Stennis formula grant number 2006-34135-17690. The authors wish to thank Randall Wakumoto and Nobuku Conroy of the City and County of Honolulu Department of Environmental Services. Special thanks to NFN Hamdani, and Mohammad Safeeq for assisting in the field data collection. Finally, the authors wish to thank three anonymous reviewers for their constructive comments.

\section{References}

Agricultural Finance Corporation (AFC) Ltd (2001) Report on Evaluation Study of the Scheme of soil Conservation in the Catchment of River Valley Projects and Flood Prone Rivers, Kundah Catchment, Kerala.

Government of India (2008) Common guidelines for watershed development projects. Department of Land Resources, Ministry of Rural Development, Government of India.

Joshi PK, AK Jha, SP Wani, Laxmi Joshi, and RL Shiyani (2005) Metaanalysis to assess impact of watershed program and people's participation. Comprehensive Assessment Research Report 8, Comprehensive Assessment Secretariat, International Water Management Institute (IWMI), Colombo, Sri Lanka, pp. 24.

Joshi PK, AK Jha, SP Wani, TK Sreedevi, and FA Shaheen (2008) Impact of Watershed Program and Conditions for Success: A MetaAnalysis Approach. Global Theme on Agroecosystems Report no. 46, International Crops Research Institute for the Semi-Arid Tropics, Patancheru 502 324, Andhra Pradesh, India, pp. 24.

Kerr J, G Pangare, VL Pangare, and PJ George (2000) An Evaluation of Dryland watershed Development in India. EPTD Discussion Paper 68. International Food Policy Research Institute, Washington, DC, USA, pp. 137.

Palanisami K, and Suresh Kumar (2004) Impact Assessment of Select Watersheds in Coimbatore District on Tamil Nadu. Water Technology Centre, Tamil Nadu Agricultural University, Coimbatore, pp. 80.

Patel PP (2005) Salinity Ingress Prevention Circle, Rajkot. In: Rishab Hemani (ed) Impact of Watershed Interventions on Groundwater in Rajasamadhiyala and Downstream Villages. International Water Management Institute, Anand, Gujarat, India.

Pathak P, SP Wani, and Sudi R (2006) Gully Control in SAT Water- sheds. Global Theme on Agroecosystems Report No. 15. International Crops Research Institute for the Semi-Arid Tropics, Patancheru 502 324, Andhra Pradesh, India, pp. 29.

Ramasamy K, and K Palanisami (2002) Some Impact Indicators and Experiences of Watershed Development in Drought Prone Areas of Tamil Nadu. In: K Palanisami, Suresh Kumar and Chandrashekaran $B$ (eds.) Watershed management - Issues and policies for 21 st Century. Associated Publishing Company, New Delhi, pp. 182-191.

Rockström J, L Karlberg, SP Wani, J Barron, N Hatibu, T Oweis, A Bruggeman, J Farahani, and Z Qiang (2010) Managing water in rainfed agriculture - The need for a paradigm shift. Agricultural Water Management 97(4): 543-550.

Rosegrant M (2002) Policies and Institutions for Sustainable Water Resource Management: A Research Agenda. Challenge program on water and food, Background paper 5. International Water Management Institute (IWMI), Colombo, Sri Lanka, pp. 35.

Sastry G, YVR Reddy, and HP Singh (2002) Appropriate Policy and Institutional Arrangements for Efficient management of Rainfed watersheds in 21 st Century. In: K Palanisami, Suresh Kumar, and Chandrashekaran B (eds.) Watershed Management - Issues and Policies for 21 st Century. India: Associated Publishing Company. pp. 228324.

Secklar D, U Amarasinghe, D Molden, R De Silva, and P Barker (1998) World water demand and supply 1990 to 2025: Scenarios and issues. Research Report 19, International Water Management Institute (IWMI), Colombo, Sri Lanka, pp.52.

Sahrawat KL, SP Wani, TJ Rego, G Pardhasaradhi, and KVS Murthy (2007) Widespread deficiencies of sulphur, boron and zinc in dryland soils of the Indian semi-arid tropics. Current Science 93 (10): 1 6.

Shiferaw B, C Bantilan, and SP Wani (2006) Policy and institutional issues and impacts of integrated watershed management: Experiences and lessons from Asia. In: Shiferaw B and Rao KPC (eds.) Integrated management of watersheds for agricultural diversification and sustainable livelihoods in Eastern and Central Africa: Lessons and experiences from semi-arid South Asia. Proceedings of the International Workshop, 6-7 December 2004, Nairobi, Kenya, pp. 37-52.

Shiklomanov A Igor (1999) World water resources and their use. International Hydrological Programme, UNESCO's Intergovernmental Scientific Programme in water resources. State Hydrological Institute, St. Petersburg.

Sikka AK, Subhash Chand, M Madhu, and JS Samra (2000) Report on Evaluation Study of DPAP watersheds in Coimbatore District. Central Soil and water Conservation Research and Training Institute, Research Centre, Uthagamandalam, Tamil Nadu.

Sreedevi TK, SP Wani, R Sudi, MS Patel, T Jayesh, SN Singh, and Tushaar Shah (2006) On-site and off-site impact of watershed development: A case study of Rajasamadhiyala, Gujarat, India. Global Theme on Agroecosystems Report No. 20. International Crops Research Institute for the Semi-Arid Tropics, Patancheru 502 324, Andhra Pradesh, India, pp.52.

Sreedevi TK, SP Wani, and P Pathak (2007) Harnessing Gender Power and Collective Action through Integrated watershed Management for Minimizing Land Degradation and Sustainable Development. Journal of Financing Agriculture 36 (1):23-32.

Sreedevi TK, SP Wani, R Sudi, Harshavardhana K Deshmukh, SN Singh, and Marcella D'Souza (2008) Impact of Watershed Development in Low Rainfall Region of Maharashtra: A case study of Shekta Watershed. Global Theme on Agroecosystems Report No. 49. International Crops Research Institute for the Semi-Arid Tropics, Patancheru 502 324, Andhra Pradesh, India, pp. 52.

Wani SP, P Pathak, TK Sreedevi, HP Singh, and P Singh (2003a) Effi- 
cient Management of rainwater for Increased crop Productivity and Groundwater Recharge in Asia. In: Kijne W, Barker R and Molden $D$ (eds.) Water productivity in agriculture: Limits and opportunities for improvement. Cab International, Wallingford, UK, pp. 199-216. Wani SP, HP Singh, TK Sreedevi, P Pathak, TJ Rego, B Shiferaw, and SR lyer (2003b) Farmer-Participatory Integrated Watershed Management: Adarsha Watershed, Kothapally, India: An Innovative and Upscalable Approach. Case 7. In: RR Harwood and AH Kassam (eds.) Research towards integrated natural resource management: Examples of research problems, approaches and partnerships in action in the CGIAR. Interim Science Council and Centre Directors Committee on Integrated Natural Resource Management, Consultative Group on International Agricultural Research, Washington, DC, USA, Food and Agriculture Organization, Rome, Italy, pp. 123 - 147.

Wani SP and YS Ramakrishna (2005) Sustainable Management of Rainwater Through Integrated watershed Approach for Improved rural Livelihood. In: Sharma BR, Samra JS, Scott C and SP Wani (eds.) Watershed management challenges: Improved productivity, resources and livelihoods. International Water Management Institute (IWMI), Colombo, Sri Lanka, pp. 39-60.

Wani SP, TK Sreedevi, TSV Reddy, B Venkateshvaralu, and CS Prasad (2008a) Community watersheds for improved livelihoods through consortium approach in drought prone rainfed areas. Journal of Hydrological Research and Development 23 (1): 55-77.

Wani SP, PK Joshi, KV Raju, TK Sreedevi, JM Wilson, Amita Shah, PG Diwakar, K Palanisami, S Marimuthu, AK Jha, YS Ramakrishna, SS Meenakshi Sundaram, and Marcella D'Souza (2008b) Community Watershed as a Growth Engine for Development of Dryland Areas. A Comprehensive Assessment of Watershed Programs in India. Global Theme on Agroecosystems Report No. 47, International Crops Research Institute for the Semi-Arid Tropics, Patancheru 502 324, Andhra Pradesh, India, pp. 156.

http://www.rlc.fao.org/en/tierra/micro.htm 